\title{
Measuring The Efficiency of Indonesian Sharia Rural Banks: Two Stage Approach
}

\author{
Rindang Nuri Isnaini Nugrohowati* \\ Departement of Economics, Faculty of Economics, Islamic University of Indonesia \\ *Corresponding Author: rindangnuri@uii.ac.id
}

Recieved: August 2018 | Revised: December 2018 | Accepted: January 2019

\begin{abstract}
In this case, one unique characteristic of Sharia Rural Bank (BPRS) as compared to commercial banks is that its operation is limited only to one provincial base. On the basis of this characteristic, the paper aims to measure the efficiency level of BPRS in Indonesia over the period of 2012 to 2015 in accordance with the regional zones. The first stage was conducted by measuring the bank's efficiency level with Data Envelopment Analysis, while the second stage was done by analyzing factors influencing the efficiency level of a bank by panel data regression method. Test results show that the average efficiency of BPRS in each region has not reached an optimal level of efficiency. Some of the internal factors that affect the efficiency level are the ratio of Operational Revenue Operational Ratio indicating a negative and significant effect while the Minimum Capital Adequacy Ratio delineating a positive and significant effect on bank efficiency. Meanwhile, Total Assets, Non Perfoming Financing and Return on Assets have no significant effect on efficiency. The macro factors of interest rate variables or BI Rate and inflation are proven to have a positive and significant effect on the efficiency of BPRS.
\end{abstract}

Keywords: Efficiency, Internal factor and macro factor, Two Stage Approach JEL Classification: G21

How to Cite: Nugrohowati, R. (2019). Study on The Efficiency of Indonesian Sharia Rural Banks: Two Stage Approach. Jurnal Ekonomi Pembangunan: Kajian Masalah Ekonomi dan Pembangunan, 20(1). doi:https://doi.org/10.23917/jep.v20i1.6692

DOI: https://doi.org/10.23917/jep.v20i1.6692

\section{Introduction}

For over more than two decades since its inception in 1992, the development of the sharia banking industry has been showing a favorable growth pace. It has experienced varied growth rates in line with the economic conditions and various influential factors. As of November 2016, the sharia banking industry has established a network of 13 Sharia Banks (BUS), 34 Sharia Business Units (UUS) and 164 Sharia Rural Banks (BPRS) with a total network of offices reaching 2,465 which is almost evenly spread throughout the archipelagic country of Indonesia. In terms of micro-scale BPRS also pinpointed a positive growth. This is delineated by the total assets of BPRS during 2012 to 2016 which kept on increasing by $94.89 \%$ to Rp9.15 trillion or soaring to $23.72 \%$ annually. In the same period, BPRS' asset growth was also accompanied by increasing Third Party Funds and financing by $98.15 \%$ and $87.35 \%$ to Rp5.82 trillion and $\mathrm{Rp} 6.66$ trillion or having an increase of $24.54 \%$ and $21,84 \%$ respectively annually (Otoritas Jasa Keuangan, 2017).

BPRS wasinitially established to serve people who have no access to modern banking services. On this account, BPRS is consistently encouraged to develop its business for having an important role in increasing the growth of small and medium micro enterprises (SME's) as the main financing 
Jurnal Ekonomi Pembangunan: Kajian Masalah Ekonomi dan Pembangunan, 20 (1), 2019, 28-49

objects of BPRS to drive the economy of the real sector. This is in line with the research conducted by Anwar (2010) highlighting that sharia banks have better performance than conventional banks on models that incorporate SME sector financing elements as one of the output components of the model. Shariah-compliant banks have higher average of SME sector financing portfolios than those of conventional bank.

BPR and BPRS have different characteristics as compared to public banks. The fact that its operation is limited to one province makes its performance be determined by the different characteristics of each region. In accordance with the Regulation of Financial Services Authority (POJK) Number 3 / POJK.03 / 2016 on Sharia People Financing Bank, the rules governing BPRS are divided into four zones. The division of the zone is based on the regional economic potential and the level of competition of financial institutions in the area concerned. Higher economic potential and tighter competition between financial institutions is classified as zone one, while zone four is normally indicated with lower economic potential and less competitive financial institutions. Thus, BPRS performance in big cities will be different from that in small towns because of ease of access to public banks in these areas. For example, BPRS located in the region of East Indonesia is expected to perform better than the Jabodetabek area. This is due to the fact that the public banks in East Indonesia are more difficult to access with the looser competition level than banks in the Greater Area of Jakarta which has easier access and tighter competition levels. Thus, the people in the East Indonesia Region will use BPRS services morfe frequently than those of commercial banks which encourages higher performance.

Although the performance of BPRS in small towns is thought to be better than that in big cities, it is disconcerting that the current development of BPRS faces major challenges. The current tendency of general banks to expand its business into small towns and villages creates tighter competition between BPRS and commercial banks. In addition, financial support, information technology and qualified human resources have pushed public banks to expand their micro-market. Given such conditions, BPRS are required to increase its resilience and competitiveness by enhancing bank efficiency. This is in line with the policy direction of the Financial Services Authority from 2017 to 2020 on the efficiency of the Financial Services Industry to support increasing competitiveness in an effort to lower credit interest rates or lower capital costs (Otoritas Jasa Keuangan, 2017). Measurement of efficiency levels is increasingly needed along with the rapid development of the banking industry in Indonesia.

Table 1. BPRS Financing Based on Financing Groups

\begin{tabular}{|c|c|c|c|c|c|c|c|}
\hline \multirow{2}{*}{$\begin{array}{c}\text { Financing } \\
\text { Groups }\end{array}$} & \multirow{2}{*}{2013} & \multirow{2}{*}{2014} & \multirow{2}{*}{2015} & \multicolumn{4}{|c|}{2016} \\
\hline & & & & AGS & SEP & OKT & NOV \\
\hline SME's & $2,620,263$ & $3,005,858$ & $3,377,987$ & $3,643,769$ & $3,473,147$ & $3,467,101$ & $3,498,449$ \\
\hline $\begin{array}{c}\text { Portion of } \\
\text { total }(\%)\end{array}$ & 59 & 60 & 59 & 56 & 54 & 53 & 53 \\
\hline $\begin{array}{l}\text { Besides } \\
\text { SME's }\end{array}$ & $1,813,230$ & $1,999,051$ & $2,387,184$ & $2,842,086$ & $2,974,698$ & $3,026,501$ & $3,092,767$ \\
\hline $\begin{array}{l}\text { Portion of } \\
\text { total (\%) }\end{array}$ & 41 & 40 & 41 & 44 & 46 & 47 & 47 \\
\hline Total & $4,433,492$ & $5,004,909$ & $5,765,171$ & $6,485,856$ & $6,447,845$ & $6,493,602$ & $6,591,216$ \\
\hline
\end{tabular}

Source: Statistik Perbankan Syariah Tahun 2016 
Measurement of efficiency levels is increasingly needed along with the rapid development of the banking industry in Indonesia. In order to survive amidst tighter competition with commercial banks, especially in microfinance segments, it is important that BPRS measure its efficiency level and determine the remedial measures to make it more efficient. Knowing the efficiency level of the bank will lead the bank to know its ability in optimizing its resources (Firdaus \& Hosen, 2013). Until now, several studies on the level of efficiency of BPRS have been carried out, but measurements on efficiency and solution have been generalized. There have been no studies that measure the level of efficiency of BPRS by considering the characteristics of each region. Considering that BPRS has different characteristics between regions, in this study efficiency measurements were carried out by classifying BPRS based on regional zones. Grouping based on regional zones aims to see whether BPRS located in regions that have higher economic potential and tighter competition of financial institutions make banks more efficient or vice versa. By knowing the level of efficiency of BPRS according to the regional zone, the formulation of strategies and corrective steps can be adjusted to the conditions of each region.

Currently, the bank's efficiency rating in many countries worldwide has continued to grow since efficiency level in the banking industry is one of the performance parameters. Staub, Souza, and Tabak (2008) conducted a study on bank efficiency levels in Brazil indicating that banks in Brazil tend to have lower economic costs than those in Europe and the United States. Meanwhile, sharia banks in Indonesia are still less efficient compared to conventional banks, primarily because sharia banking is still in the stage of expansion and has not reached the economic scale as that of conventional banks. As disclosed by Firdaus and Hosen (2013) the level of efficiency of sharia banks in Indonesia has not reached an optimal level of efficiency. Meanwhile, Fadhlullah (2015) through a case study at BPD
Syariah Bank in Indonesia concluded that the technical efficiency of BPD bank has not reached the optimal efficiency level of 100 percent. On average, BPD with bigger assets tends to be more efficient than those with medium and small assets.

The progresses on efficiency measurement have called for a research procedure known as Two-Stage Data Envelopment Analysis (Firdaus \& Hosen, 2013). This approach will provide a comprehensive overview of the efficiency level of a bank as well as determine the determinants of efficiency (Subandi \& Ghozali, 2013). Research on efficiency determination has been conducted in various countries, one of which is the one by Harimaya and Kondo (2016) which addresses the impact of branch opening on bank efficiency in Japan. The results reveal that regional banks can lower cost inefficiencies by expanding branch networks to a certain level. Delis and Papanikolaou (2009) who conducted a research on bank efficiency determinants by using semi-parametric methods concluded that some determinants such as bank size, industry concentration and investment environment have a positive impact on bank efficiency.

Another study conducted by Omar, Rahman, Yusof, Shabri, and Rasid (2006) delineated that bank size is proven to have no significance in improving bank efficiency, but the utilization of technology and human resource capability has a major impact on high productivity growth. According to Hassan and Sanchez (2007) who took a banking case study in Latin America, it is proven that the level of capitalization, profitability ratio, interest rate differential and GDP growth positively affect bank efficiency, while inflation rate has a negative effect on efficiency. Meanwhile, Abidin and Endri (2009) who conducted a research on macroeconomic variables and banking efficiency in Indonesia revealed that interest rate variables affect the technical efficiency of the bank negatively, while inflation and exchange rates are positively affected. 
Jurnal Ekonomi Pembangunan: Kajian Masalah Ekonomi dan Pembangunan, 20 (1), 2019, 28-49

Based on some of the previous researces, it is necessary to re-examine the efficiency and efficiency determinants in particular for BPRS. To obtain a comprehensive overview of the efficiency level of BPRS, a Two-Stage Methodology approach was developed. The first step employs the measurement of efficiency with the Data Envelopment Analysis (DEA) method, and the second step looks at internal factors and external factors that affect the efficiency level of BPRS. Given the different characteristics of BPRS between regions, this study will measure the efficiency level of BPRS based on 4 regional zones. Knowing the efficiency level, it will be possible to determine the improvement steps for BPRS that are yet to achieve $100 \%$ efficiency. Furthermore, a new test was conducted on determination or factors affecting the efficiency level of BPRS. It is expected that this study will be considered as an input for policy stakeholders in formulating strategic measures to encourage BPRS competitiveness in accordance with the potential of the region.

\section{Research Methodology}

The data were obtained from financial statements published by Indonesian Bank and
Financial Services Authority. The sampling was conducted by way of purposive sampling based on BPRS criteria that semi-annual financial report is available in full during the period of 2012 to 2015. The sample was selected based on the completeness of data owned by BPRS especially information on total assets, operational costs, operating income, financing, non-performing loan (NPL), Return on Assets (ROA) and others. The sample of BPRS was selected based on regional zone divided into four zones in accordance with the Regulation of Financial Services Authority (POJK) Number 3 / POJK.03 / 2016 on Sharia Rural Banks.

The division of regional zones is determined based on the economic potential of the region and the level of competition of financial institutions in the relevant district or city area. Zone 1 shows areas with higher economic potential and more stringent financial competition, while zone 4 shows the region with lower economic potential and the looser competition of financial institutions. List of Regency and City Name according to the zones is contained in the attachment of the Power Distribution Services Authority Number 46/ SEOJK.03/2016.

Table 2. Data Sharia Rural Bank (BPRS) According to the Regional Zone (Data as of Desember 2015)

\begin{tabular}{|c|c|c|}
\hline Regional Zone & Sampel Area & $\begin{array}{l}\text { Sampel } \\
\text { BPRS }\end{array}$ \\
\hline Zone 1 & $\begin{array}{l}\text { Kota Medan, Kota Jakarta Selatan, Kab Bandung, Kab Bogor, Kab } \\
\text { Semarang, Kab Tangerang }\end{array}$ & 16 \\
\hline Zone 2 & $\begin{array}{l}\text { Kota Banda Aceh, Kab. Deli Serdang, Kaota Pekanbaru, Kab Cianjur, } \\
\text { Kab Bekasi, Kota Depok, Kota Cimahai, Kab Cilacap, Kab Banyumas, } \\
\text { Kab Magelang, Kab Klaten, Kota Surakarta/Solo, Kota Yogyakarta, Kab } \\
\text { Kediri, Kab Malang, Kab Sidoarjo, Kab. Gresik, Kab Pamekasan, Kab } \\
\text { Serang, Kab Bandung }\end{array}$ & 27 \\
\hline Zone 3 & Daerah Istimewa Yogyakarta dan Jawa Timur & 3 \\
\hline Zone 4 & $\begin{array}{l}\text { Kab Aceh Tengah, Kab Aceh Besar, Kab Pidie, Kab Aceh Jeumpa, Kota } \\
\text { Langsa, Kota Lhokseumawe, Kab Agam, Kab Solok, Kota Sawahlunto, } \\
\text { Kab Kampar, Kab Way Kanan }\end{array}$ & 13 \\
\hline & Total & 59 \\
\hline
\end{tabular}



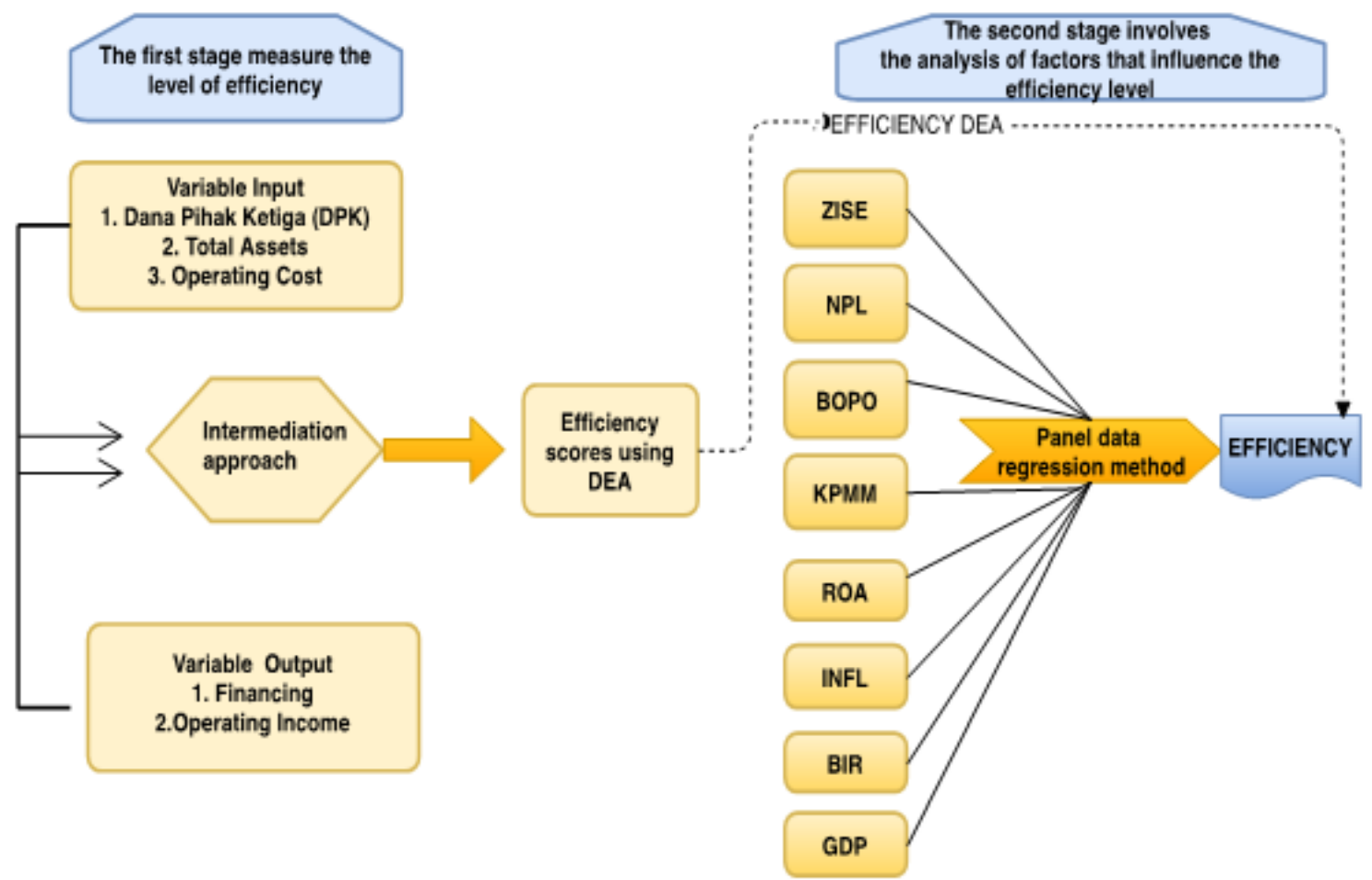

Figure 1. Thinking Framework

This research consisted of two stages. The first stage was efficiency measurement of efficiency with DEA non parametic approach using Banxia software, while the input and output variables were determined using intermediation approach. To see the difference in the level of efficiency according to the regional zone, one way Anova was tested. The second step involved estimation of external and internal factors affecting bank efficiency as illustrated in Figure 1.

\subsection{Specification of Bank Input and Output}

Considering that the intermediation approach is the right approach to evaluate the performance of financial institutions in general because of their characteristics as financial intermediation, this study used intermediation approaches to determine banks' inputs and outputs. In addition, the intermediation approach is known to have been widely used in research to measure the level of banking efficiency undertaken in different countries. An intermediary approach looks at banking institutions as intermediaries between surplus units and deficit units. In other words, the intermediation approach considers the bank as an intermediary between depositors and lenders. The difference between the production approaches and the intermediation approach lies in the determination of inputs and outputs. In a third-party deposit or deposit production approach, it is considered as an output or a product produced by a bank, while in the intermediary deposit approach or DPK it is considered an input which will eventually result in an outflow of output to the public. Thus, the inputs in intermediation approaches are deposits and resources used, while the outputs are loans and other income. 
Jurnal Ekonomi Pembangunan: Kajian Masalah Ekonomi dan Pembangunan, 20 (1), 2019, 28-49

\subsection{Data Analysis Method}

2.2.1 The First Phase of Efficiency Measurement with Data Envelopment Analysis (DEA).

To measure the banking efficiency in this study, the researcher used a non parametic approach known as Data Envelopment Analysis (DEA). DEA is a measure of efficiency by involving a number of inputs to produce a number of outputs to be used for decision making and efficiency improvements. The advantages of the non parametric approach are that they do not require too much information, assumptions and samples (Subandi \& Ghozali, 2013). In this case the DEA is able to suggest the extent of the improvements the company needs in terms of inefficient resource use. Therefore, this research uses DEA non parametric method by using Banxia Fontier software in measure efficiency level.

There are two models commonly used in the DEA approach: the Constant Return to Scale (CRS) model and the Variable Return to Scale (VRS) model. The result of DEA calculation with CRS approach is also known as the Overall Effectiveness (Overall Effciensy). The result of DEA calculation using VRS approach is also referred to as Technical Effciency. Data Envelopment Analysis (DEA) is used to estimate the technical efficiency score (TE), pure technical efficiency (PTE), and efficiency scale (ES) by using intermediation approach. The TE and PTE scores ranged from $0-1$. The value of closer to 1 indicated that the bank was judged to be more efficient. The division of TE scores by the PTE score will produce ES ranging from 0-1.

$\mathrm{SE}=\mathrm{TE} / \mathrm{PTE}$

Where:

$\mathrm{SE}=$ Scale Effciency

$\mathrm{TE}=$ Overall Effciency (CRS model)

PTE = Technical Effciency (VRS model)

Selection of input and output variables to measure efficiency level using DEA method is as follows:
Table 3. Input-output of the DEA model

\begin{tabular}{|c|c|c|}
\hline Variable & Definition & Reference \\
\hline $\begin{array}{l}\text { Input } \\
\text { DPK } \\
\text { Total assets } \\
\text { Operating } \\
\text { cost }\end{array}$ & $\begin{array}{l}\text { Wadiah Deposits } \\
\text { Fund } \\
\text { Total assets } \\
\text { Operating cost }\end{array}$ & $\begin{array}{l}\text { Firdaus and } \\
\text { Hosen, (2013) } \\
\text { Widiarti, Siregar, } \\
\text { and Andati } \\
\text { (2015)which } \\
\text { is in line with } \\
\text { their financial } \\
\text { indicators } \\
\text { namely the total } \\
\text { increasing asset, } \\
\text { stable ROA of } \\
\text { around 2-3\%, and } \\
\text { their Operating to } \\
\text { Income Cost ratio } \\
\text { of about } 66-83 \% \text {. } \\
\text { Furthermore, } \\
\text { we apply data } \\
\text { panel estimation } \\
\text { to estimate the } \\
\text { determinant of } \\
\text { this efficiency; the } \\
\text { result shows the } \\
\text { bank's type, the } \\
\text { Non Performing } \\
\text { Loan (NPL }\end{array}$ \\
\hline $\begin{array}{l}\text { Output } \\
\text { Financing } \\
\text { Operating } \\
\text { Income }\end{array}$ & $\begin{array}{l}\text { Murabahah } \\
\text { Financing } \\
\text { Funds } \\
\text { distribution } \\
\text { income }\end{array}$ & $\begin{array}{l}\text { Firdaus and } \\
\text { Hosen, (2013) } \\
\text { Widiarti et al. } \\
(2015)\end{array}$ \\
\hline
\end{tabular}

After carrying out efficiency measurement using DEA, the next step was to look at the differences in the efficiency of BPRS from four zones. The analytical method used is an average difference test using One Way Anova.

\subsubsection{The Second Phase: Determination of Data Efficiency with Data Panel}

The first step in this research is the estimation of efficiency score using DEA. The second stage will analyze the effect of internal and external bank factors as independent variables to dependent variables, namely the efficiency of the DEA measurements using panel data regression. Panel data regression was used in view of the efficiency determination because the data panel form is a combination of Sharia BPRS latitude data and semester time series of the period of 2012 to 2015 . In the data panel model analysis, 
there are three types of approaches consisting of common effect approach, fixed effect approach, and random effect approach. The three approaches used in data panel analysis are explained below:

1. Pooled Least Square (PLS) approach or common effect

Estimation of common effects is a simple regression technique for estimating panel data. Basically, estimates on common effects combine only time-series data with cross-sectional data regardless of time and individual differences. Thus, OLS method can also be used in estimating panel data models. The assumption of data behavior is considered to be equal regardless of time.

2. Constant Slope Approach but with Different Intercept between Individuals (Fixed Effect). One of the challenges of data panel procedures is the difficulty to meet the consistent intercept assumption and slope assumptions. To overcome this, the researcher inserted the dummy variables in the data panel to enable different parameter values between cross-section and time-series.

3. Random Effect Approach

The decision to include dummy variables in a fixed effect model is known to reduce the degree of freedom that will ultimately reduce the efficiency of the estimated parameters. The data panel model which involves correlation between error terms due to time change because of different observation is solved by error component model or also called random effect model.

Given that panel data is a combination of timeseries and cross-section, the model can be written with the following:

$\mathrm{EFF}_{\mathrm{it}}=\boldsymbol{\beta}_{0}+\boldsymbol{\beta}_{1} \mathrm{SIZE}_{\mathrm{it}}+\boldsymbol{\beta}_{2} \mathrm{NPL}_{\mathrm{it}}+\boldsymbol{\beta}_{3} \mathrm{BOPO}_{\mathrm{it}}+$ $\beta_{4} \mathrm{KPPM}_{\mathrm{it}}+\boldsymbol{\beta}_{5} \mathrm{ROA}_{\mathrm{it}}+\boldsymbol{\beta}_{6} \mathrm{INFL}_{\mathrm{it}}+\boldsymbol{\beta}_{7} \mathrm{BIR}_{\mathrm{it}}+\boldsymbol{\beta}_{8}$ GDP $_{\text {it }}+\mu_{\text {it }}$ $\mathrm{i}=1,2, \ldots, \mathrm{N} \quad ; \mathrm{t}=1,2, \ldots, \mathrm{T}$

where:

$\mathrm{EFF}=$ Efficiency

SIZE $=$ Total Assets

NPL $=$ Non-Performing Loan to Total Credit

$\mathrm{BOPO}=$ Operational Costs on Operating Revenue

$\mathrm{KPMM}=$ Minimum $\quad$ Capital Adequacy Requirement

ROA $=$ Profit Before Taxes to Average Total Assets

INFL = Inflation

$\mathrm{BIR}=\mathrm{BI}$ Rate

$\mathrm{GDP}=$ Regional GDP

\section{Results And Discussion}

3.1 Measurement of Islamic Bank Sharia Efficiency Level (BPRS) Semester I Year 2012 to Semester II Year 2015

This discussion will highlight the measurement of efficiency level of Syariah Rural Banks (BPRS) using Banxia Frontier Analysis (BFA) software. Overall, the efficiency level of efficiency of BPRS in four regional zones throughout the period of 2012 to 2015 has fluctuated and thus overall has yet to reach an optimal level of efficiency. Based on the measurement results through the Frontier Analisys method, the efficiency score is 0 and 1 which means that the BPR Syariah is said to be very efficient when the score is 1 . In contrast, the efficiency score which is far from 1 or approaching 0 indicates that BPRS is inefficient. The efficiency level of each BPRS will be presented in the table in annex one.

\subsubsection{Efficiency Level of BPRS in Zone 4}

The samples taken for zone 4 were 13 BPRS located in the provinces of Aceh, North Sumatra, West Sumatra, Riau and Lampung. 


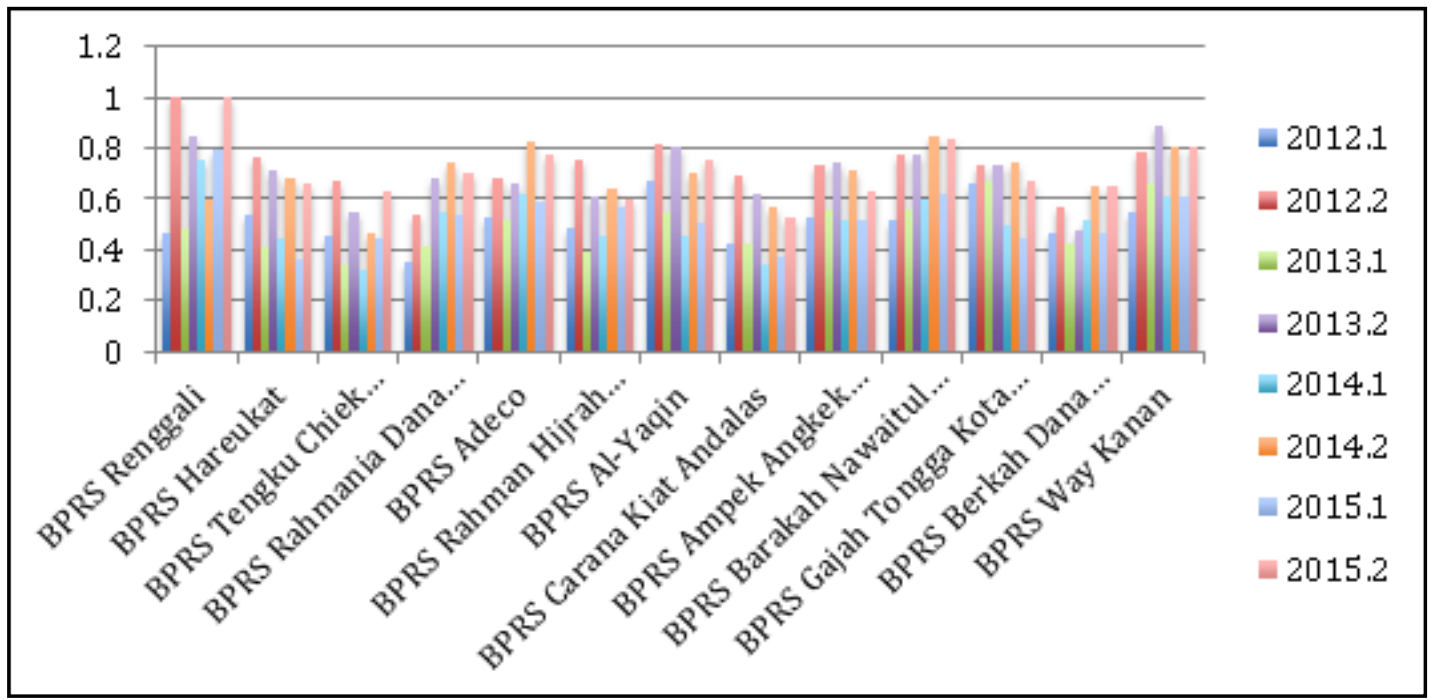

Figure 2. Efficiency Rate BPRS in Zone 4

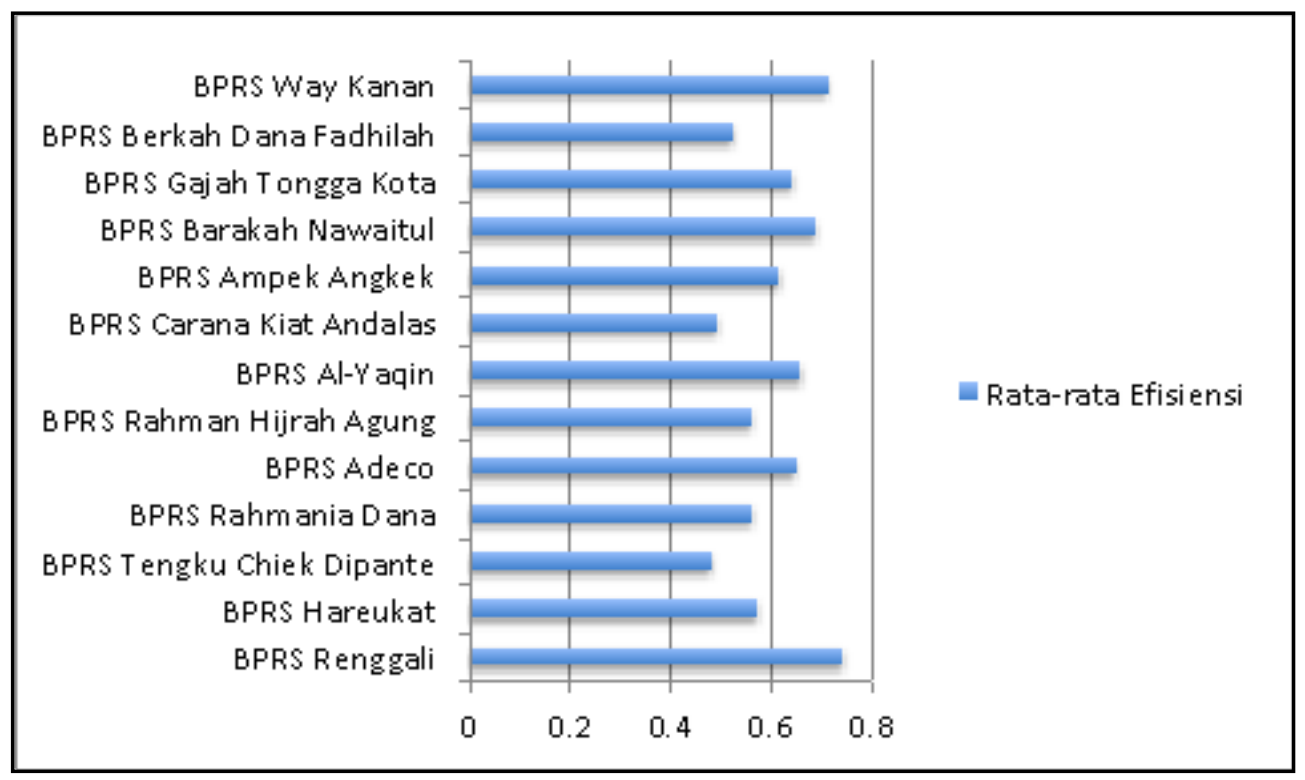

Figure 3. Average BPRS Efficiency Level in Zone 4

Overall, the efficiency level of 13 BPRS indicated a fluctuating trend, only the Renggali BPRS capable of achieving 100\% efficiency level in the second half of 2015. On the other hand, the lowest efficiency level was achieved by BPRS Tengku Chiek Dipate in the first semester of 2014. On average it is indicated that the average efficiency of BPRS in zone 4 is about $0.6 \%$. It is thus conclusive that the average level of efficiency of BPRS is still quite low. Zone 4 is a region which is less competitive and is usually located in the city district with low economic potential. In zone 4 , rarely do we see easy access to public banks. Hence, it is highly likely that BPRS becomes the potential first choice for people requiring banking services. In this case, the level of competition may positively and negatively affect the level of banking efficiency. This is due to high market 
concentration resulting in low competition in the banking sector leading to inefficient bank performance. Banks that are in a low competitive environment result in a lack of sustainability. This is in line with what is disclosed by Muljawan, Hafidz, Astuti, and Oktapiani (2014) that there is a negative correlation between the level of competition and efficiency. Lower level of banking competition can lead to lower bank efficiency. Furthermore, the inefficiency is compensated by raising the margin. On the contrary, a high level of competition can encourage banks efficiency to compete and maintain their business sustainability.

Apergis and Alevizopoulou (2011) also revealed that efficiency is one of the mostimportant assets for banks as banking operates in highly competitive environments. By taking a banking case study in Europe, they revealed that overall Germany, Denmark and Australia have the most efficient banking system, while Luxembourg and France are in the final rank. Maudos, Pastor, And, and Quesada (2000) disclosed the reasons for the different level of efficiency of banking in Europe that is due to the bank's characteristic and market characteristic. In particular, the level of risk measured by capital costs and asset composition can affect the efficiency of the bank, while market characteristics such as environmental or regulatory conditions as well as banking technology can determine the level of bank efficiency. Environmental conditions as expressed by Lozato (1997) can be demonstrated by differences in demand for product and banking services. The difference in demand can be affected by population density and per capita income.

As of BPRS, it is known to have inefficient operationals and difficulties to obtain capital assistance under structural problems. In order to increase its role, BPRS must be operated on a certain scale and should be supported by a larger Capital Adequacy Ratio (KPPM) ratio to absorb potential risks. Capital limitation is a major factor causing BPRS to not achieve economic scale. This is attributed to limited capital resulting in the inability to recruit qualified HR, inability to provide reliable IT facilities, inability to realize good corporate governance and inability to develop competitive products and services. All these things are known to trigger the potential of fraud and mismanagement deteriorating BPRS performance and leading to great losses impeding the realization of economic of scale. The inability to achieve economic of scale may lead to inefficiencies for BPR and BPRS. In order to increase the bank's ability to absorb the risk, Financial Services Authority issued the rules set out in POJK Number 3 / POJK.03 / 2016 that the amount of capital provision in the framework of establishment of BPRS is adjusted to the regional zone.

\subsubsection{Efficiency of BPRS in Zone 3 Area}

Out of the three BPRS samples located in zone 3, the level of efficiency was best achieved by BPRS Al Mabrur Babadan with average value of $0.90 \%$. The increase in efficiency level significantly occurred in 2012 from the original value of $0.53 \%$ in the first semester to $100 \%$ in the second semester. In the next period, BPRS Al Mabrur Babadan was able to maintain its efficiency although the first and second semester of 2015 experienced a slight decline. In this case, it was rare to find a bank capable of maintaining its efficiency value steadily from time to time. There are many factors to inhabit banks from maintaining its stable efficiency Widiarti et al. (2015)which is in line with their financial indicators namely the total increasing asset, stable ROA of around $2-3 \%$, and their Operating to Income Cost ratio of about $66-83 \%$. Furthermore, we apply data panel estimation to estimate the determinant of this efficiency; the result shows the bank's type, the Non Performing Loan (NPLpointed out that internal bank factors such as Non Performing Loan (NPL), Loan to Deposit Ratio (LDR), Bank Size, Cost Efficiency Ratio, and Capital Adequacy Ratio (CAR) significantly affect the efficiency of banks in Indonesia. 


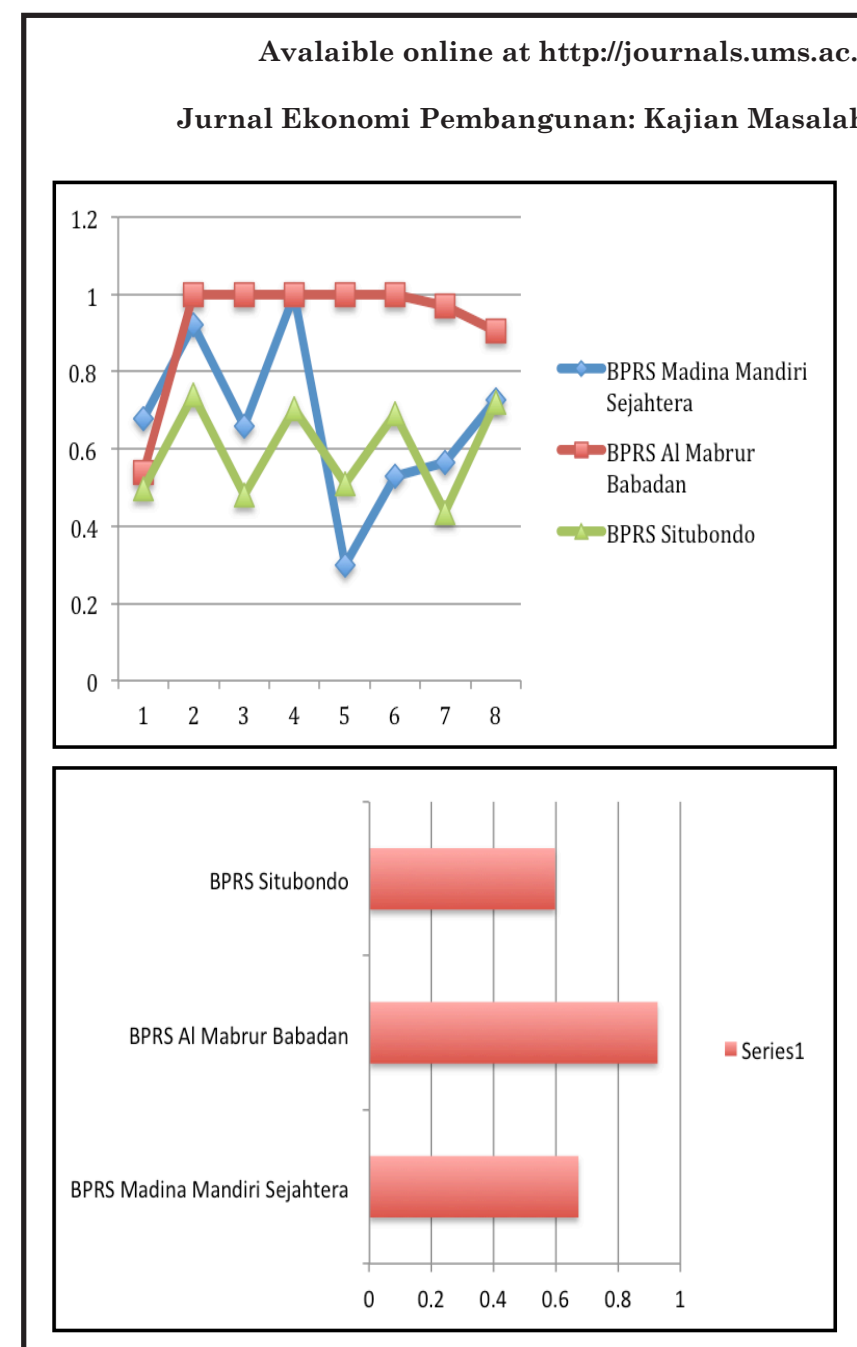

Figure 4. Efficiency and Average Efficiency Level of 3 BPRS in the Area of Zone 3

As for intermediary function, Third Party Funds in the form of savings are known to be inputs owned by the bank, while channeling funds to the public in the form of financing is an output for the bank. Measurement of bank efficiency will see how the input can produce levels of output. Banks are said to be efficient when it can manage inputs in such a way to produce optimal output. In fact, it is not easy to realize an efficient bank performance and not all banks can achieve $100 \%$ of efficiency.

\subsubsection{BPRS Efficiency in Zone 2}

Zone 2 consists of 103 (one hundred three) areas but this study only involved 27 BPRS from the provinces of Aceh, North Sumatra, Riau, West Java, Central Java, DIY, East Java, Banten and Bali. Based on the measurement of BPRS efficiency level during the first semester of 2012 until the second semester of 2015 , it was revealed that those banks experienced a fluctuating trend. During the research period, there were several BPRS that could achieve optimal efficiency level. Those with the $100 \%$ efficiency level were BPRS Arta Fisabililah in the second half of 2013, BPRS Al Barokah in the second semester of 2012 and 2013, BPRS Al Hijrah Amanah in the first half of 2012, BPRS Bhakti Haji in the first semester of 2015, BPRS Unawi Barokah in the first semester of 2014 and last was BPRS Syariat Fajar Sejahtera Bali in the first and second semester of 2013 and 2014 as well as the second semester of 2015 .

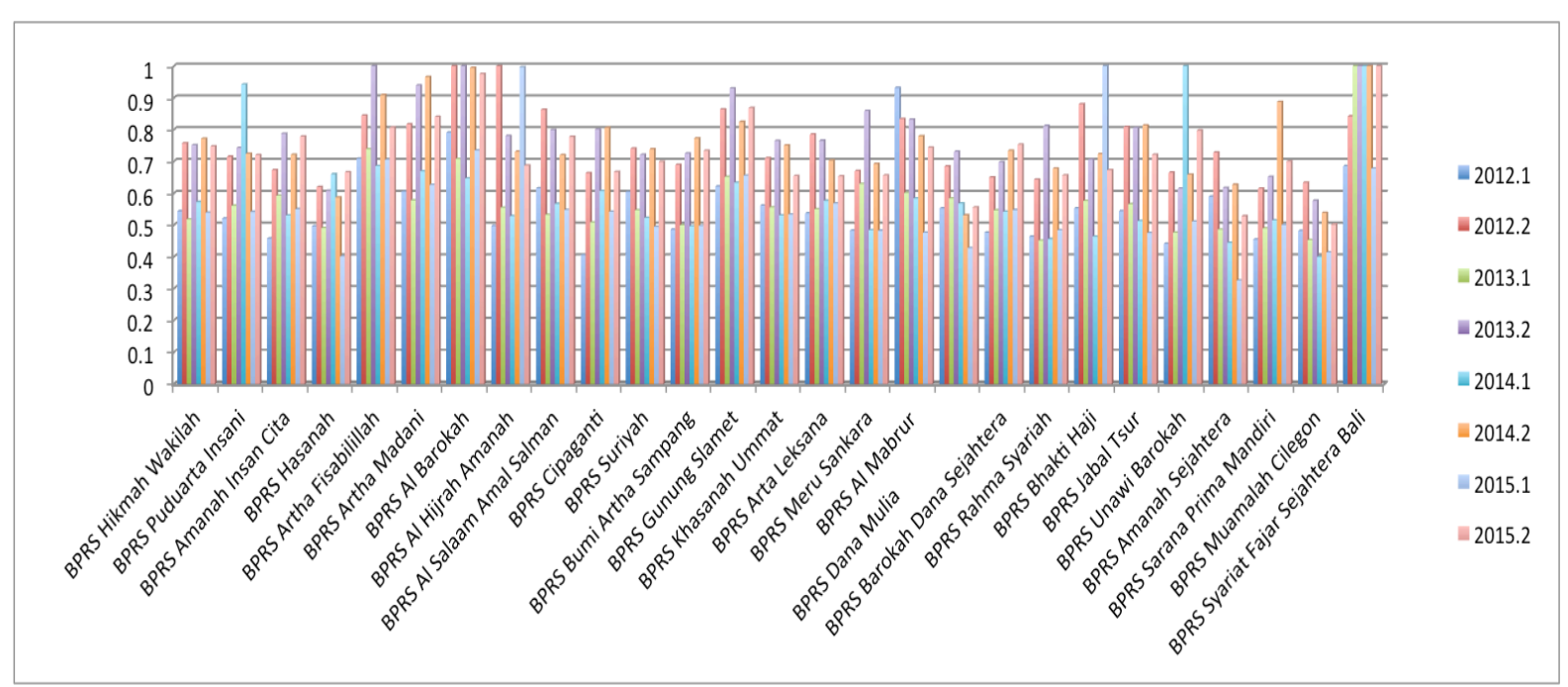

Figure 5. Efficiency Rate BPRS in Zone 2 
Avalaible online at http://journals.ums.ac.id, Permalink/DOI: 10.23917/jep.v20i1.6692

Jurnal Ekonomi Pembangunan: Kajian Masalah Ekonomi dan Pembangunan, 20 (1), 2019, 28-49

Table 4. BPRS Hasanah Target Input and Output (Second Semester Period 2015)

\begin{tabular}{lllcc}
\hline \multirow{3}{*}{ Input } & Variable & $\begin{array}{c}\text { Actual (Juta } \\
\text { Rupiah) }\end{array}$ & $\begin{array}{c}\text { Target (Juta } \\
\text { Rupiah) }\end{array}$ & $\begin{array}{c}\text { Potential } \\
\text { Improvement }\end{array}$ \\
\hline \multirow{6}{*}{ Output } & Wadiah Savings & 174,94 & 174,94 & $0 \%$ \\
& Total assets & 7883535 & 7883535,00 & $0 \%$ \\
& Operating costs & 1470674 & 1470674,00 & $0 \%$ \\
& Financing & 6298660 & 9451989,19 & $50.06 \%$ \\
& Operating Income & 1553943 & 2331901,14 & $50.06 \%$ \\
\hline
\end{tabular}

Source: Data Processed

The benefit of efficiency measurement using DEA is that it can suggest how much improvements are needed by companies that are inefficient in terms of use of resources. Suppose that the BPRS Hasanah in the second semester of 2015 has an efficiency value of 0.6664 or $66.64 \%$. To make it achieve $100 \%$ efficiency level, the bank is encouraged to raise the total financing and operating income of $50.06 \%$.

\subsubsection{Efficiency of BPRS in Zone 1}

Zone 1 is an area with higher economic potential and more rigorous financial competition. The high levels of competition between banks are required so banks can manage their existing funds more efficiently. The challenges faced by BPRS located in zone 1 are not only competition between sharia banks but competition with conventional commercial banks. Ease of access to public banks in this region resulted in the public having many elternative choices in using banking services. Hence, Figure 6 will explain whether higher competition in this area can be followed by increasingly higher competitiveness.

Based on the testing results, it is known that BPRS achieving $100 \%$ of efficiency was BPRS Al Washliyah in the first semester of 2013, BPRS Al Ihsan in the first semester of 2015, BPRS Harta Insan Karimah Parahyangan in the first semester of 2012 and BPRS Harta Insan Karimah in the second half of the year 2012 until the second semester of 2013. The best efficiency performance was shown by BPRS Harta Insan Karimah with an average efficiency value of $0.95 \%$ during the research period. Meanwhile, the lowest efficiency level occurred in BPRS Rifatul Ummah with a value of $0.28 \%$ in the first semester of 2012 . A potential improvement for BPRS Rif'atul Ummah is by way of lowering the wadiah savings target of $80.95 \%$. In addition to achieving $100 \%$ efficiency level, BPRS Rif'atul Ummah also needs to increase its funding and operating income by $254.40 \%$.

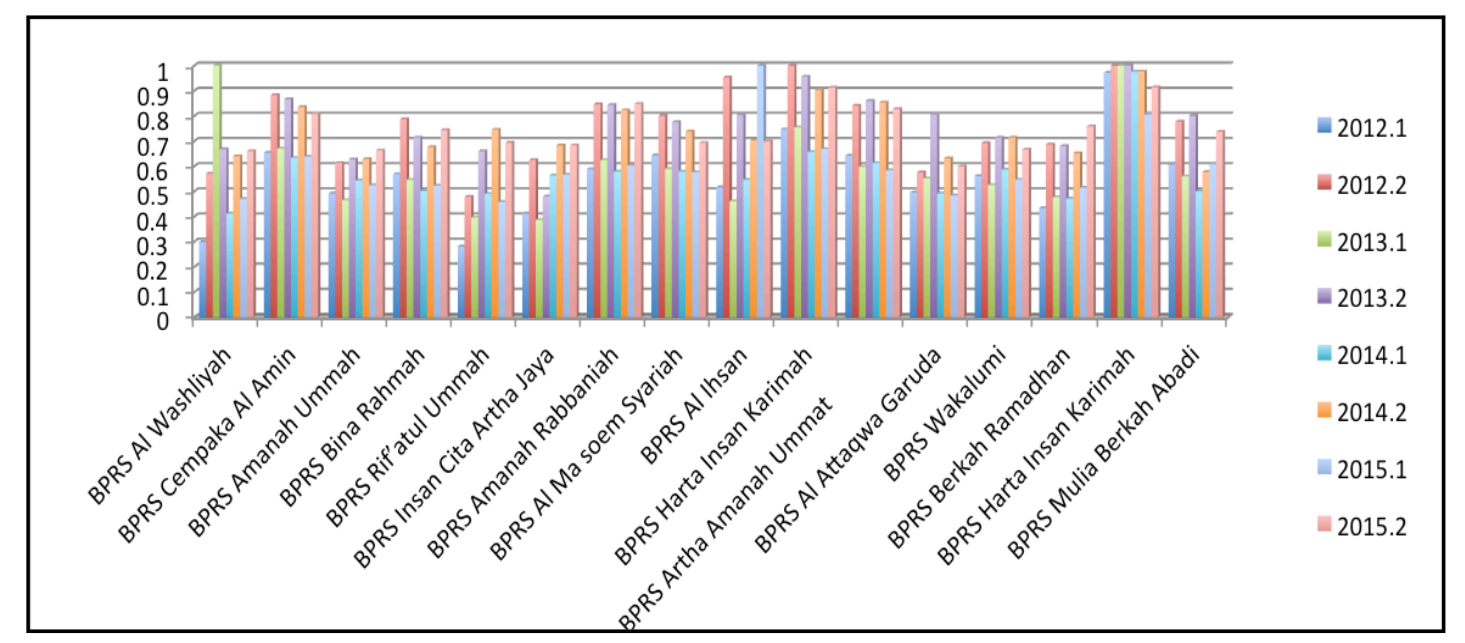

Figure 6. Efficiency Rate BPRS in Zone 1 
Avalaible online at http://journals.ums.ac.id, Permalink/DOI: 10.23917/jep.v20i1.6692

Jurnal Ekonomi Pembangunan: Kajian Masalah Ekonomi dan Pembangunan, 20 (1), 2019, 28-49

Tabel 5. BPRS Rif'atul Ummah Target Input dan Output (Second Semester Period 2013)

\begin{tabular}{llccc}
\hline \multirow{2}{*}{ Variable } & $\begin{array}{c}\text { Actual (Juta } \\
\text { Rupiah) }\end{array}$ & $\begin{array}{c}\text { Target (Juta } \\
\text { Rupiah) }\end{array}$ & $\begin{array}{c}\text { Potential } \\
\text { Improvement }\end{array}$ \\
\hline \multirow{3}{*}{ Input } & Wadiah Savings & 2342,32 & 446,19 & $-80,95 \%$ \\
& Total Assets & 11647467,00 & 11647467,00 & $0 \%$ \\
& Operating cost & 329063,00 & 329063,00 & $0 \%$ \\
& Financing & 6939486 & 24593569,19 & $254,40 \%$ \\
& Operating Income & 423071,00 & 1499365,50 & $254,40 \%$ \\
\hline
\end{tabular}

Source: Data Processed

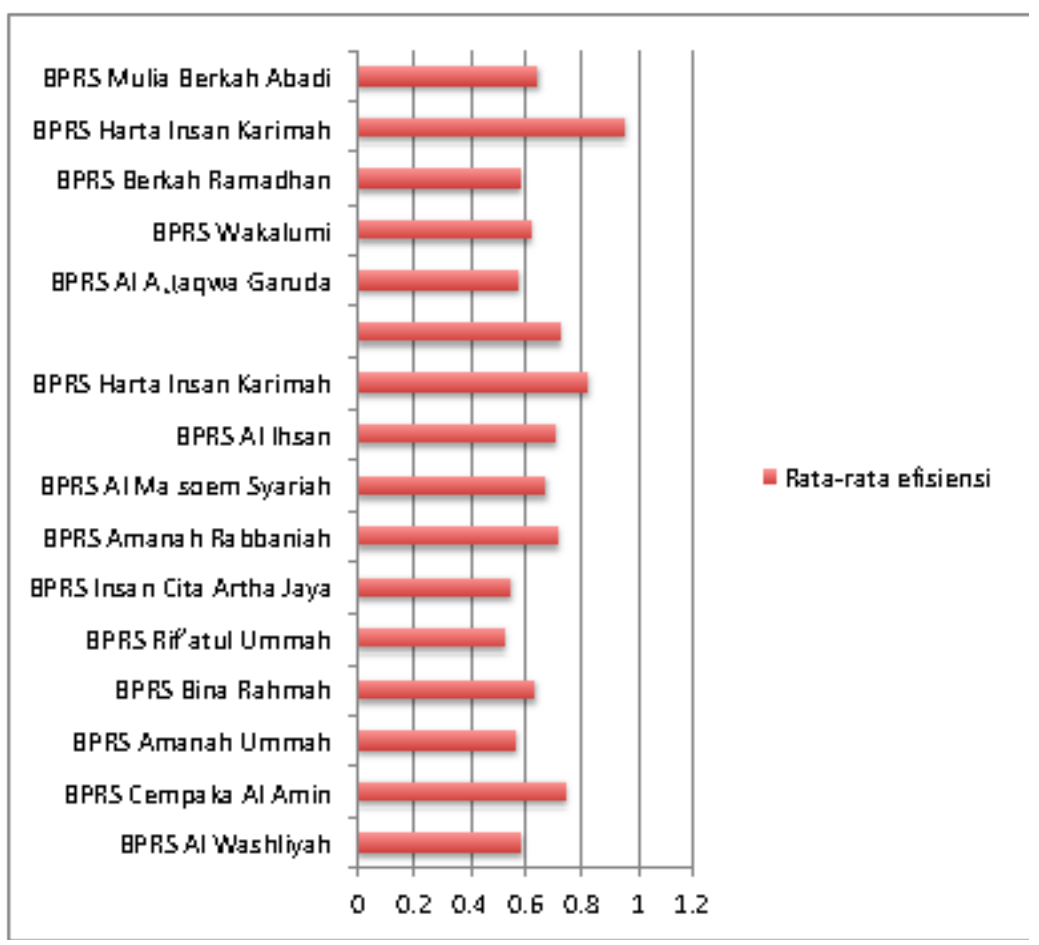

Figure 7. Average Efficiency of BPRS in Zone 1

In this case, it is possible to measure efficiency level through two approaches, namely input approach and output approach. The input approach sees how much inputs can be reduced to produce the same quantity of output, while the output approach answers how much quantity of output can be proportionally increased. Overall, the average efficiency level amounted to $0.67 \%$. Thus, it is conclusive that the efficiency level of BPRS in zone 1 has not been optimal. Many factors are known to contribute to the failure of BPRS in achieving efficient level. Rahmawati and Hosen (2012) revealed that at the moment the competition between banks, especially sharia banks has returned to the level of profit sharing, which differs sharply between sharia banks. Bank Perkreditan Rakyat is widely known by the public as a bank with public financing as its primary activity. However, in its operational activities financing activities can only be made when the bank receives funds from the public. Thus, the main challenge faced by BPRS is to build the public trust to save their funds in the bank. Many strategies can be made to attract Third Party Funds, one of which is by promising high yields.

However high yields also result in cost inefficiencies. Hence, the challenge not only lies in how to boost high deposit funds but also on how to manage them to produce optimal output. 
Some effort to be taken by the bank is by trying to improve internal efficiency first before taking other external measures. Internal efforts can be made by allocating optimal inputs and minimizing costs as low as possible. According to Mardanugraha (2005), the best way to improve the employees' productivity is by managing funds. It can be done through the bank's operational activities such as collecting and channeling funds. For this purpose, the bank requires a reliable Human Resources (HR) to maintain the prudential principle.

\subsubsection{Difference in the Level of Effiiency Among BPRSs}

The measurement of BPRS efficiency in four regional zones discloses fluctuating efficiency levels, but overall it is conclusive that the average efficiency in each region has yet to reach optimal level. Although regional zoning divisions illustrate the level of competition and regional potential, it is not a major factor to determine the level of bank efficiency. Measurements of bank efficiency emphasize more on seeing how the input performance can produce certain output levels. In this case, the bank is said to be efficient when it is able to manage inputs in such a way as to produce maximum output.

The measurement of the average difference test shows that the level of efficiency of BPRSs in the four zones of the region does not have a significant difference. This can be seen from the results of the Anova test which shows that the significance value is greater than alpha $5 \%$. Thus it can be concluded that the level of efficiency of BPRS in regions that have economic potential and high levels of competition is not much different from BPRS located in zone four, namely regions with economic potential and low levels of competition.

The level of efficiency that has not been optimal is due to the big challenges faced by BPRS throughout the region. Through PBI No. 14/22 / PBI / 2012, Bank Indonesia requires each Commercial Bank to channel MSME Credit or financing at least $20 \%$ of the total financing portfolio. This makes the competition level of
Commercial Banks and BPRS almost evenly distributed throughout the region. In this case there is a potential for credit transfers from BPRS to commercial banks under the scheme of People's Business Credit (KUR). In addition, BPRSs compete with other financial institutions such as cooperatives and other microfinance institutions.

Table 3.3 Results of Different Average Estimates ANOVA

\begin{tabular}{lccccc}
\hline Efficiency & $\begin{array}{c}\text { Sum of } \\
\text { Squares }\end{array}$ & df & $\begin{array}{c}\text { Mean } \\
\text { Square }\end{array}$ & F & Sig. \\
\hline $\begin{array}{l}\text { Between } \\
\text { Groups }\end{array}$ & .049 & 3 & .016 & 1.637 & .191 \\
$\begin{array}{l}\text { Within } \\
\text { Groups }\end{array}$ & .550 & 55 & .010 & & \\
Total & .599 & 58 & & & \\
\hline
\end{tabular}

Source: Data Processed BY SPSS

Hafidz, Rachmanira, and Octia (2013) measuring the level of competition of commercial banks with rural banks using the HerfindahlHirschman Index (HHI) and finding competition between commercial banks and rural banks in the provision of microcredit. BPRs and commercial banks also compete to give microcredits because they operate in the same areas. His research also links the level of competition and efficiency between Commercial Banks and Rural Banks. The results show that the level of efficiency in commercial banks is better when compared to rural banks. This is as a result of the high cost of Funds for Credit (HDPK) and overhead costs $(\mathrm{OCH})$ borne by BPR. To attract markets, BPRs tend to provide higher interest rates on deposits compared to commercial banks. On the other hand, commercial banks are able to reduce operational costs because they have a wider market, more varied sources of funds, better infrastructure and facilities and more adequate human resources. Furthermore, the comparison between HII and efficiency shows that the higher level of competition results in lower levels of BPR efficiency. Similar things are also faced by Sharia Rural Banks (BPRS). 
Avalaible online at http://journals.ums.ac.id, Permalink/DOI: 10.23917/jep.v20i1.6692

Jurnal Ekonomi Pembangunan: Kajian Masalah Ekonomi dan Pembangunan, 20 (1), 2019, 28-49

Table 6. Estimates of Internal Factor Models and External Factors Affecting Efficiency

\begin{tabular}{crrrr}
\hline Variable & Coefficient & Std. Error & t-Statistic & Prob. \\
\hline C & 0.616981 & 0.052849 & 11.67451 & 0.0000 \\
\hline TA & $1.15 \mathrm{E}-10$ & $1.28 \mathrm{E}-10$ & 0.896546 & 0.3704 \\
\hline NPF & -0.000182 & 0.000329 & -0.551473 & 0.5816 \\
\hline BOPO & -0.253551 & 0.037729 & -6.720268 & 0.0000 \\
\hline KPMM & $8.80 \mathrm{E}-05$ & $3.91 \mathrm{E}-05$ & 2.248306 & 0.0250 \\
\hline ROA & $-2.31 \mathrm{E}-05$ & 0.000212 & -0.109012 & 0.9132 \\
\hline INFL & 0.020721 & 0.003198 & 6.479547 & 0.0000 \\
\hline BIR & 0.017470 & 0.007039 & 2.481968 & 0.0134 \\
\hline GDP & $8.53 \mathrm{E}-08$ & $1.02 \mathrm{E}-07$ & 0.834698 & 0.4043 \\
\hline R-squared & 0.218587 & Mean dependent var & 0.321804 \\
\hline Adjusted & 0.205085 & S.D. dependent var & 0.134860 \\
R-squared & 0.120238 & Sum squared resid & 6.693679 \\
\hline S.E. of regression & 16.18956 & Durbin-Watson stat & 2.657609 \\
\hline F-statistic & 0.000000 & & \\
\hline Prob(F-statistic) & Source: Data Processed by OSEVIEWS &
\end{tabular}

Although faced with the challenges of high competition, BPRS still have the opportunity to increase their existence through linkage programs with Commercial Banks. There are three linkage program models that can be carried out by BPRS namely executing, channeling and joint financing. With these partnership models, the relationship between BPRS and Commercial Banks can be complementary and supportive. However, the concern is that so far the linkage program has become an expensive fund for BPRS, so it is necessary to review how the partnership program can become a low-cost fund for BPRS without reducing reasonable profits for commercial banks.

\subsection{Estimated Factors to Affect Efficiency Level of BPRS}

Based on panel data processing conducted in several stages, it came to light that the Random Effect model comes up with the best estimate result as shown in Table 6.

Based on the data processing as shown in the abovementioned table, it can be interpreted that this regression model has $\mathrm{R}$-squared value of 0.2185 . This indicates that the variation of independent data can only explain the dependent variable of the efficiency of $21.85 \%$, while $78.15 \%$ is explained by other variables outside the model.

\subsubsection{The Impact of Bank Internal Factors on Efficiency}

Many factors are also known to determine bank efficiency level such as internal bank factors in the form of financial indicators. Internal factors are micro or specific factors that can determine the bank efficiency level. The first financial indicator to be analyzed to see its effect on efficiency is the total asset that indicates the size of the bank. The test on the size of the bank which is proxied by total assets shows no significant effect on the efficiency of BPRS. This is observable from the probability value at above $0.05 \%$ indicating that the bank size does not have a significant effect on the efficiency of BPRS. This result is in line with that revealed by (Omar et al., 2006) that took a case study in Malaysia and disclosed that bank size was not an important factor in improving bank efficiency. In contrast, the utilization of technology and human resource capability has a major impact on high productivity growth. This is not in line with the research conducted by Abidin and Endri (2009) which highlights that on average, 
the bank with bigger assets is more efficient than that with middle and small assets. The result of the study is also in line with that conducted by Delis and Papanikolaou (2009) indicating that a number of determinants such as bank size have a positive impact on bank efficiency. While Sardar, Azeem, and Ahmed (2017) who investigated bank efficiency in Pakistan found that assets had a positive effect on bank efficiency.

The effect of NPF on efficiency is shown by coefficient value of -0.000182 with probability value equal to 0.5816 that is greater than alpha $5 \%$. In other words, NPF has a negative effect on efficiency but not significantly. The results of this study are not in line with the study by Widiarti et al. (2015)which is in line with their financial indicators namely the total increasing asset, stable ROA of around 2-3\%, and their Operating to Income Cost ratio of about $66-83 \%$. Furthermore, we apply data panel estimation to estimate the determinant of this efficiency; the result shows the bank's type, the Non Performing Loan (NPL pinpointing that the internal factors of the bank, one of which is Non Performing Loans (NPF) significantly affects the efficiency of banks in Indonesia. NPF is a comparison between nonperforming loans, credit summation with lesser, doutbtful, and loss quality, with the total credit. The high rate of NPF is attributed to two things, namely because the problematic credit is getting bigger or the total amount of financing is getting smaller. The NPF increase that is triggered by the growing credit of the problem will affect the bank's efficiency. The high level of non-performing loans can threaten the bank's capital, because it functions to absorb the risks. However, if the high NPF is resulted from the low total financing due to reduced credit demand and reduced credit disbursements, the NPF is thought to have no significant effect on efficiency.

The effect of CAR on efficiency is shown by the coefficient value of 0.00088 with a probability value of 0.0250 that is smaller than alpha $5 \%$. This means that KPMM has a positive and significant effect on bank efficiency. When bank capitalization is higher, the performance of BPRS will be more efficient. These results are in line with studies conducted by Widiarti et al. (2015) which is in line with their financial indicators namely the total increasing asset, stable ROA of around 2-3\%, and their Operating to Income Cost ratio of about $66-83 \%$. Furthermore, we apply data panel estimation to estimate the determinant of this efficiency; the result shows the bank's type, the Non Performing Loan (NPL and Karimah, Novianti, and Effendi (2016) concluding that the bank's capital adequacy ratio has a significant effect on the bank's efficiency. The Minimum Capital Adequacy Ratio (CAR) is a ratio between capital and Risk Weighted Assets used to measure the bank's ability to absorb the risk. When the ratio of KPMM is high, the capital capability to absorb the risk will be greater and thus, the bank is judged to be more efficient. In this case, the bank capital has a significantly huge role to absorb risk. Capital limitation is a major factor that impedes BPRS from achieving economic scale. This is so because limited capital will result in the inability to recruit qualified HR, inability to provide reliable IT facilities, inability to realize good corporate governance and inability to develop competitive products and services. All these things can trigger the potential of fraud and mismanagement that degrades BPRS performance and even incur losses making it impossible to achieve economic of scale. The fact that it fails to achieve economic of scale has led to inefficiencies for BPR and BPRS.

The effect of BOPO ratio on bank efficiency is shown by coefficient value of -0.253551 with probability value of 0.0250 that is smaller than alpha $5 \%$. In other words, BOPO has a negative and significant effect on BPRS efficiency. BOPO is a ratio between operational costs and operating income, which is one of the indicators of bank efficiency level. Banking is said to be efficient if the BOPO ratio decreases, so the relationship between BOPO and efficiency is negative. These results are in line with studies conducted by Widiarti et al. (2015)which is in line with their financial indicators namely the total increasing asset, stable ROA of around $2-3 \%$, and their 
Jurnal Ekonomi Pembangunan: Kajian Masalah Ekonomi dan Pembangunan, 20 (1), 2019, 28-49

Operating to Income Cost ratio of about $66-83 \%$. Furthermore, we apply data panel estimation to estimate the determinant of this efficiency; the result shows the bank's type, the Non Performing Loan (NPL whose test results show that BOPO Ratio which is a Cost Efficiency ratio significantly affects the bank efficiency level in Indonesia. Meanwhile, the effect of ROA ratio on bank efficiency shows the coefficient value of -0.000231 with probability value of 0.9132 greater than alpha $5 \%$. This means that ROA has a negative effect but not significant to efficiency. These results are not in line with the studies conducted by Subandi and Ghozali (2013) and Hassan (2006) indicating that efficiency is highly correlated with ROA and ROE. In the sample taken, many BPRS are found to have a negative ROA ratio, which would affect the probability calculation of ROA regression to efficiency.

\subsubsection{Effect of Macro Factor on BPRS Efficiency}

This research also aims to address how macro variable influence efficiency level of BPRS in Indonesia. Macro variables or external factors are variables unrelated to bank management but reflect the economic environment that affects banking operations and performance. The influence of inflation variable to efficiency is shown by coefficient value of 0.020721 with probability value of 0.0000 . These results indicate that inflation has a positive and significant effect on the efficiency of BPRS in Indonesia. When inflation is higher, the bank is judged to be more efficient. This result is in line with the study conducted by Endri, (2015) which reveals that inflation and exchange rates have a positive effect on efficiency. However, this is not in line with Garza-Garcia (2012) study taking a case study in Mexico which found that inflation rates lowered the efficiency of the bank. In contrast, Hassan and Sanchez (2007) who conducted a research in Latin America revelaed that the inflation rate affects the efficiency of the bank negatively.

Inflation has two contradictory sides. When inflation is too low, the economy will slacken.
However, on the other hand, the high inflation will lower the purchasing power of the people. As a policy response of the soaring inflation, the central bank will normally control the value of inflation by raising interest rates. This results in the higher cost of capital payable by the debtor. Thus, an increase in inflation will limit the demand for personal credit. The positive impact of inflation on BPRS efficiency is suspected because BPRS runs its operational system using the principles of sharia which is based on the profit sharing principle. With the rise in interest rates as a result of rising inflation, debtors look for financing alternatives with much lower capital costs. Islamic banks that are not based on interest are an alternative option for people who want to apply for financing. Thus, when inflation is increasing, people will tend to switch to sharia banking. This will clearly explain the relations between high rate of inflation and higher level of bank efficiency.

The effect of interest rate on efficiency is shown by coefficient value of 0.017470 with probability of 0.0134 that is smaller than $5 \%$. This means that interest rates have a positive and significant effect on the efficiency of BPRS in Indonesia. This result is in line with what is proposed by Delis and Papanikolaou (2009) and Hassan and Sanchez (2007) but not in line with Endri (2015) study which reveals that variable interest rates negatively affect the technical efficiency of banks. High interest rates lead to a greater value of NIM because of the larger disparity between credit interest rates and deposit interest rates. High NIMs make it unnecessary for the bank to operate at a low cost, resulting in inefficiencies. This has the same predisposition to the impact of inflation on bank efficiency. The increase of interest rates will lead to higher capital costs. As an effect, this results in diminishing intensity of financing in conventional banking. On the other hand, the people will seek for financing alternatives that are not based on interest, ie sharia banking or BPR Sharia.

The test on the effect of GDP on efficiency indicates that GDP has a positive but not 
significant effect toward BPRS efficiency. This is shown by coefficient value of 0,01747 with probability of 0,404 larger than $5 \%$. This is the reason why the efficiency calculation of BPRS in 4 regional zones equally shows poor result. Thus, the regional potential difference measured by GDP does not affect the efficiency level of BPRS. The low efficiency of BPRS is due to the inefficiencies in its operational activities. Some of the factors known to greatly contribute to this are competition with public bank financial institutions that are currently seeking to expand its business in the micro market. On the other hand, BPRS' competitiveness is currently at the low, both in terms of product and service innovation. The low competitiveness has resulted in great financial loss in some BPRS' financial statement. On the other hand, BPRS also faces competition between sharia banks in the form of price competition or profit margin. When BPRS wants to withdraw their Third Party Funds, they must provide attractive rates or profit margins to the public. The higher the profit margin offered, the higher the public interest to save their funds at BPRS. However, the operational burden borne by banks is also getting higher, leading to the inevitable inefficiency in BPRS operational. Other studies conducted by Garza-Garcia (2012) and Delis and Papanikolaou (2009) come up with different results that GDP growth affects the efficiency of the bank. Anwar (2010) research asserts that macro GDP has no significant effect on efficiency.

\section{Conclusions and Suggestions}

On the basis of the research, it is conclusive that overall, the average of BPRS efficiency in four regional zones has yet to reach optimal level. Of all the observed BPRS, only few BPRs that attained $100 \%$ efficiency levels in certain periods, but there was no BPRS capable of maintaining optimum efficiency levels during the research period. In this case, there was no significant difference between the levels of efficiency among regional zones. Some internal bank factors that affected the efficiency level of BPRS were BOPO and KPMM, while Total Assets, NPF and ROA had no significant effect on efficiency. For macro variables, BI Rate and inflation were proven to have a positive and significant effect on BPRS efficiency, while GDP was seen to have no significant effect on efficiency.

Based on these findings, it is necessary to strategically improve the competitiveness of BPRS in order to sustain its competitiveness against both commercial banks and other sharia banks. As seen from the internal side of BPRS, it is necessary to undertake several strategies such as improvement of credit disbursement by focusing on micro, small and medium industries (SMEs). This can be achieved by increasing the employee's productivity in managing the funds while still keeping in mind the prudential principles. Other recommended measurements to achieve economies of scale and to increase competitiveness are performing mergers between BPRS especially for small-scale BPRS. Although in this case the total asset will not have a significant effect on efficiency, the recommended merger measurement can reinforce the company's capital structure. The increase in capital capability of the bank is highly essential because the primary function of capital is to absorb the risk. The increasingly complex operational activities of the bank must be supported by strong capitalization. Therefore, it is necessary that the bank maintain the value of the Minimum Capital Provision of Liabilities within the range set by the regulator. Meanwhile, macro variables are variables that are not related to bank management but reflect the economic environment that may affect banking operations and performance. Thus, the bank is highly required to pay attention to external factors in determining the most appropriate strategy to develop its product and more competitive services.

\section{Acknowlegment}

I would like to express my gratitute to all contributors who helped on this research until it is published in the Jurnal Ekonomi Pembangunan. Without their helps, the research would not have been completed successfully. 
Jurnal Ekonomi Pembangunan: Kajian Masalah Ekonomi dan Pembangunan, 20 (1), 2019, 28-49

\section{Reference}

Abidin, Z., \& Endri. (2009). Kinerja Efisiensi Teknis Bank Pembangunan Daerah: Pendekatan Data Envelopment Analysis ( DEA ). Jurnal Akuntansi Dan Keuangan, 11, 21-29.

Anwar, M. (2010). Efisiensi Perbankan di Indonesia: Bank Syari, ah vs Bank Konvensional. Buletin Ekonomi Moneter Dan Perbankan, 18(3), 307-334.

Apergis, N., \& Alevizopoulou, E. (2011). Bank efficiency: Evidence from a panel of European banks. Panoeconomicus, 58(3), 329-341. https://doi.org/10.2298/ PAN1103329A

Delis, M. D., \& Papanikolaou, N. I. (2009). Determinants of bank efficiency: evidence from a semi-parametric methodology. Managerial Finance, 35(3), 260-275.

Endri. (2015). Variabel Makroekonomi Dan Efisiensi Perbankan Di Indonesia. Seminar Nasional Ekonomi Manajemen Dan Akuntansi Fakultas Ekonomi Universitas Padang, 73-80.

Fadhlullah, A. H. (2015). EFISIENSI BANK PEMBANGUNAN DAERAH: PENDEKATAN STOCHASTIC FRONTIER. Signifikan, 4(1), 1-16.

Firdaus, Muhammad F, \& N, M. (2013). Efficiency of Islamic Banks Using Two Stage Approach of Data Envelopment Analysist. In Bulletin of Monetary, Economics and Banking.

Firdaus, Muhammad Faza, \& Hosen, M. N. (2013). Efficiency of Islamic Banks Using Two Stage Approach of Data Envelopment Analysis. Buletin Ekonomi Moneter Dan Perbankan, 16(2), 155-176.

Garza-Garcia, J. G. (2012). Title : Determinants of bank efficiency in Mexico : a two-stage analysis Determinants of bank efficiency in Mexico : a two-stage analysis. Working Paper Series.

Hafidz, J., Rachmanira, S., \& Octia, T. (2013).
Tingkat Persaingan dan Efisisnei Bank Umum dan BPR di Pasar Kredit Mikro di Indonesia. Working Paper, 1-8.

Harimaya, K., \& Kondo, K. (2016). Effects of branch expansion on bank efficiency : evidence from Japanese regional banks. Managerial Finance, 42(2), 82-94. https:// doi.org/10.1108/MF-11-2014-0278

Hassan, M. K. (2006). the X-Efficiency in Islamic Banks. Islamic Economic Studies, 13(2), 30.

Hassan, M. K., \& Sanchez, B. (2007). Efficiency Determinants and Dynamic Efficiency Changes. Working Paper, (December).

Karimah, S., Novianti, T., \& Effendi, J. (2016). Kajian Efisiensi Bank Umum Syariah di Indonesia Efficiency of Islamic Bank in Indonesia. Kajian Efisiensi Bank Umum Syariah Indonesia, 4(7), 33-43.

Lozato, A. (1997). Profit Efficiency for Spanish Savings Banks. European Journal of Operational Research, 98(2), 381-394.

Mardanugraha, E. (2005). Evaluasi Merger Perbankan di Indonesia Ditunjau Melalui Fungsi Biaya Parametik. Jurnal Ekonomi Dan Pembangunan Indonesia, VI(1), 1-15.

Maudos, J., Pastor, J. M., And, F. P., \& Quesada, J. (2000). Asymmetric Price-Benefits Auctions. Games and Economic Behavior, 33(1), 48-71. https://doi.org/10.1006/ game.1999.0772

Muljawan, D., Hafidz, J., Astuti, R. I., \& Oktapiani, R. (2014). Faktor-faktor Penentu Efisiensi Perbankan Indonesia serta. Working Paper.

Omar, M. A., Rahman, A. R. A., Yusof, R. M., Shabri, M., \& Rasid, M. E. S. M. (2006). Efficiency of commercial banks in Malaysia. Asian Academy of Management Journal of Accounting and Finance, 2(2), 19-42. https://doi.org/10.4018/978-1-5225-2814-2

Otoritas Jasa Keuangan. (2017a). Laporan Capaian Kinerja OJK 2012 - 2017. Report.

Otoritas Jasa Keuangan. (2017b). Siaran Pers. 
Avalaible online at http://journals.ums.ac.id, Permalink/DOI: 10.23917/jep.v20i1.6692

Jurnal Ekonomi Pembangunan: Kajian Masalah Ekonomi dan Pembangunan, 20 (1), 2019, 28-49

9-11.

Rahmawati, R., \& Hosen, M. N. (2012). Efficiency of Fund Management of Sharia Banking in Indonesia ( Based On Parametric Approach ). International Journal of Academic Research in Economics and Management Sciences, 1(2), 144-158. https://doi. org/10.1007/s00170-003-1756-1

Sardar, A., Azeem, M. M., \& Ahmed, T. (2017). Islamic Banks: Efficiency and its Determinants in Pakistan Linked references are available on JSTOR for this article: Pakistan Banks : Eff. Islamic Studies, 50(3), 423-434.

Staub, R. B., Souza, G., \& Tabak, B. M. (2008). Evolution of Bank Efficiency in Brazil: A DEA Approach. Working Paper Series, 39(5), 561-563.
Subandi, \& Ghozali, I. (2013). Determinan efisiensi dan dampaknya terhadap kinerja profitabilitas industri perbankan di indonesia. Jurnal Keuangan Dan Perbankan, 17(No.1 Januari 2013), 123135.

Widiarti, A, Hermanto S, T. A. (2015). The Determinants of Bank's Efficiency in Indonesia. Buletin Ekonomi Moneter Dan Perbankan, 18(2), 129-156.

Widiarti, A. W., Siregar, H., \& Andati, T. (2015). The Determinants of Bank's Efficiency In Indonesia. Buletin Ekonomi Moneter Dan Perbankan, 18(2), 130-156. https://doi.org/ https://doi.org/10.21098/bemp.v18i2.520 
Avalaible online at http://journals.ums.ac.id, Permalink/DOI: 10.23917/jep.v20i1.6692

Jurnal Ekonomi Pembangunan: Kajian Masalah Ekonomi dan Pembangunan, 20 (1), 2019, 28-49

\section{Appendix}

Appendix 1: Efficiency Level of BPRS Semester I of 2012 - Semester II of 2015

\begin{tabular}{|c|c|c|c|c|c|c|c|c|c|c|c|}
\hline Nama BPRS & Kab. Kota & ZONA & 2012.1 & 2012.2 & 2013.1 & 2013.2 & 2014.1 & 2014.2 & 2015.1 & 2015.2 & AVERAGE \\
\hline BPRS Renggali & $\begin{array}{l}\text { Kab. Aceh } \\
\text { Tengah }\end{array}$ & 4 & 0.4662 & 0.9976 & 0.4885 & 0.8488 & 0.7517 & 0.596 & 0.7904 & 1 & 0.7424 \\
\hline $\begin{array}{l}\text { BPRS } \\
\text { Hareukat }\end{array}$ & $\begin{array}{l}\text { Kab. Aceh } \\
\text { Besar }\end{array}$ & 4 & 0.5351 & 0.7675 & 0.4173 & 0.7083 & 0.4395 & 0.6816 & 0.3652 & 0.6627 & 0.57215 \\
\hline $\begin{array}{l}\text { BPRS Tengku } \\
\text { Chiek Dipante }\end{array}$ & Kab. Pidie & 4 & 0.4543 & 0.6691 & 0.3416 & 0.5479 & 0.3191 & 0.461 & 0.4436 & 0.6318 & 0.48355 \\
\hline $\begin{array}{l}\text { BPRS } \\
\text { Rahmania } \\
\text { Dana Sejahtera }\end{array}$ & $\begin{array}{l}\text { Kab. Aceh } \\
\text { Jeumpa/ } \\
\text { Bireuen }\end{array}$ & 4 & 0.353 & 0.5354 & 0.4118 & 0.6793 & 0.5516 & 0.7436 & 0.5393 & 0.7066 & 0.565075 \\
\hline $\begin{array}{l}\text { BPRS Hikmah } \\
\text { Wakilah }\end{array}$ & $\begin{array}{l}\text { Kota Banda } \\
\text { Aceh }\end{array}$ & 2 & 0.5437 & 0.7578 & 0.5179 & 0.7519 & 0.5728 & 0.772 & 0.5395 & 0.7476 & 0.6504 \\
\hline BPRS Adeco & Kota Langsa & 4 & 0.5255 & 0.6833 & 0.5144 & 0.6659 & 0.6186 & 0.8299 & 0.5923 & 0.7708 & 0.6500875 \\
\hline $\begin{array}{l}\text { BPRS Rahman } \\
\text { Hijrah Agung }\end{array}$ & $\begin{array}{l}\text { Kota } \\
\text { Lhokseumawe }\end{array}$ & 4 & 0.4809 & 0.7534 & 0.3923 & 0.6111 & 0.4567 & 0.6391 & 0.5716 & 0.6034 & 0.5635625 \\
\hline $\begin{array}{l}\text { BPRS Puduarta } \\
\text { Insani }\end{array}$ & $\begin{array}{l}\text { Kab. Deli } \\
\text { Serdang }\end{array}$ & 2 & 0.5208 & 0.7153 & 0.5612 & 0.7427 & 0.9422 & 0.7244 & 0.5418 & 0.7202 & 0.683575 \\
\hline $\begin{array}{l}\text { BPRS Amanah } \\
\text { Insan Cita }\end{array}$ & $\begin{array}{l}\text { Kab. Deli } \\
\text { Serdang }\end{array}$ & 2 & 0.4583 & 0.6734 & 0.5923 & 0.7876 & 0.5304 & 0.7215 & 0.5505 & 0.7787 & 0.6365875 \\
\hline BPRS Al-Yaqin & $\begin{array}{l}\text { Kab. } \\
\text { Simalungun }\end{array}$ & 4 & 0.6733 & 0.8158 & 0.5499 & 0.8095 & 0.4548 & 0.7048 & 0.5083 & 0.7571 & 0.6591875 \\
\hline $\begin{array}{l}\text { BPRS Al } \\
\text { Washliyah }\end{array}$ & Kota Med & 1 & 2998 & 0.5717 & 1 & 0.6687 & 0.4132 & 0.6408 & 0.4717 & 0.6604 & 0.5907875 \\
\hline $\begin{array}{l}\text { BPRS Carana } \\
\text { Kiat Andalas }\end{array}$ & $\mathrm{Kab}$ & 4 & 0.421 & 0.6872 & 0.4212 & 0.6207 & 0.3427 & 0.5704 & 0.3678 & 0.5231 & 0.4942625 \\
\hline $\begin{array}{l}\text { BPRS Ampek } \\
\text { Angkek } \\
\text { Candung }\end{array}$ & Kab. Agam & 4 & 0.5262 & 0.7328 & 0.5549 & 0.7406 & 0.5205 & 0.712 & 0.5162 & 0.6303 & 0.6166875 \\
\hline $\begin{array}{l}\text { BPRS Barakah } \\
\text { Nawaitul } \\
\text { Ikhlas }\end{array}$ & Kota Solok & 4 & 0.5191 & 0.779 & 0.5535 & 0.7741 & 0.6029 & 0.8488 & 0.6228 & 0.8322 & 0.69155 \\
\hline $\begin{array}{l}\text { BPRS Gajah } \\
\text { Tongga Kota } \\
\text { Piliang }\end{array}$ & $\begin{array}{l}\text { Kota } \\
\text { Sawahlunto }\end{array}$ & 4 & 75 & 8 & 35 & 31 & 9 & 7411 & 4442 & 0.6677 & 436 \\
\hline $\begin{array}{l}\text { BPRS Berkah } \\
\text { Dana Fadhilah }\end{array}$ & Kab. Kampar & 4 & 0.4696 & 0.5716 & 0.4234 & 0.4735 & 0.5119 & 0.6467 & 0.4682 & 0.6462 & 0.5263875 \\
\hline BPRS Hasanah & $\begin{array}{l}\text { Kota } \\
\text { Pekanbaru }\end{array}$ & 2 & 4968 & 0.6202 & 0.4909 & 0.6077 & 0.66 & 0.5871 & 0.4015 & 0.6664 & 0.566325 \\
\hline $\begin{array}{l}\text { BPRS Way } \\
\text { Kanan }\end{array}$ & $\begin{array}{l}\text { Kab. Way } \\
\text { Kanan }\end{array}$ & 4 & 0.5432 & 0.7889 & 0.6645 & 0.8895 & 0.61 & 0.8051 & 0.6086 & 0.8095 & 0.7149125 \\
\hline $\begin{array}{l}\text { BPRS Cempaka } \\
\text { Al Amin }\end{array}$ & $\begin{array}{l}\text { Wil. Kota } \\
\text { Jakarta } \\
\text { Selatan }\end{array}$ & 1 & 0.6549 & 0.8839 & 0.6716 & 0.8679 & 0.6342 & 0.8366 & 0.6384 & 0.8095 & 0.749625 \\
\hline $\begin{array}{l}\text { BPRS Amanah } \\
\text { Ummah }\end{array}$ & Kab. Bogor & 1 & 0.4925 & 0.6139 & 0.466 & 0.6284 & .544 & 0.6289 & 0.5257 & 0.664 & 0.570425 \\
\hline $\begin{array}{l}\text { BPRS Bina } \\
\text { Rahmah }\end{array}$ & Kab. & 1 & 694 & 0.7874 & 0.5472 & 0.7152 & 0.502 & 0.6765 & 0.5236 & 0.7447 & 0.63325 \\
\hline $\begin{array}{l}\text { BPRS Rif'atul } \\
\text { Ummah }\end{array}$ & Kab. Bogor & 1 & 0.2822 & 0.4799 & 0.3967 & 0.6604 & 0.4909 & 0.7464 & 0.4591 & 0.6943 & 0.5262375 \\
\hline $\begin{array}{l}\text { BPRS Insan } \\
\text { Cita Artha } \\
\text { Jaya }\end{array}$ & Kab. Bogor & 1 & 0.4128 & 0.6259 & 0.3878 & 0.4806 & 0.5642 & 0.6836 & 0.5672 & 0.6841 & 0.550775 \\
\hline $\begin{array}{l}\text { BPRS Artha } \\
\text { Fisabilillah }\end{array}$ & Kab. Cianjur & 2 & 0.7092 & 0.8447 & 0.7389 & 1 & 0.6859 & 0.9091 & 0.7057 & 0.8073 & 0.8001 \\
\hline $\begin{array}{l}\text { BPRS Amanah } \\
\text { Rabbaniah }\end{array}$ & Kab. Bandu & 1 & 0.5895 & 0.8473 & 0.6251 & 0.8447 & 0.5797 & 0.8235 & 0.6031 & 0.8492 & 0.7202625 \\
\hline $\begin{array}{l}\text { BPRS Al Ma } \\
\text { soem Syariah }\end{array}$ & Kab. & 1 & 0.6444 & 0.8012 & 0.5906 & 0.7764 & 0.5793 & 0.7393 & 0.5773 & 0.6936 & 0.6752625 \\
\hline BPRS Al Ihsan & Kab. Bandung & 1 & 0.5171 & 0.9535 & 0.4623 & 0.8042 & 0.5475 & 0.7031 & 1 & 0.7002 & 0.7109875 \\
\hline
\end{tabular}




\begin{tabular}{|c|c|c|c|c|c|c|c|c|c|c|c|}
\hline Nama BPRS & Kab. Kota & ZONA & 2012.1 & 2012.2 & 2013.1 & 2013.2 & 2014.1 & 2014.2 & 2015.1 & 2015.2 & AVERAGE \\
\hline $\begin{array}{l}\text { BPRS Harta } \\
\text { Insan Karimah } \\
\text { Parahyangan }\end{array}$ & Kab. Bandung & 1 & 0.7477 & 1 & 0.755 & 0.9572 & 0.6574 & 0.9043 & 0.6693 & 0.9135 & 0.82555 \\
\hline $\begin{array}{l}\text { BPRS Artha } \\
\text { Madani }\end{array}$ & Kab. Bekasi & 2 & 0.6056 & 0.8171 & 0.5777 & 0.9396 & 0.6695 & 0.9662 & 0.6269 & 0.8404 & 0.755375 \\
\hline $\begin{array}{l}\text { BPRS Al } \\
\text { Barokah }\end{array}$ & Kota Depok & 2 & 0.791 & 1 & 0.7083 & 1 & 0.647 & 0.9953 & 0.7351 & 0.9754 & 0.8565125 \\
\hline $\begin{array}{l}\text { BPRS Al Hijrah } \\
\text { Amanah }\end{array}$ & Kota Depok & 2 & 0.4974 & 1 & 0.5546 & 0.7809 & 0.5283 & 0.7309 & 0.9969 & 0.6875 & 0.7220625 \\
\hline $\begin{array}{l}\text { BPRS Al } \\
\text { Salaam Amal } \\
\text { Salman }\end{array}$ & Kota Depok & 2 & 0.6159 & 0.8627 & 0.533 & 0.7995 & 0.567 & 0.7202 & 0.5477 & 0.7781 & 0.6780125 \\
\hline $\begin{array}{l}\text { BPRS } \\
\text { Cipaganti }\end{array}$ & Kota Cimahi & 2 & 0.4059 & 0.6637 & 0.5085 & 0.8014 & 0.6073 & 0.8064 & 0.5419 & 0.6671 & 0.625275 \\
\hline BPRS Suriyah & Kab. Cilacap & 2 & 0.6046 & 0.7406 & 0.5471 & 0.7214 & 0.5231 & 0.7387 & 0.4949 & 0.6994 & 0.633725 \\
\hline $\begin{array}{l}\text { BPRS Bumi } \\
\text { Artha Sampang }\end{array}$ & Kab. Cilacap & 2 & 0.4861 & 0.6897 & 0.4998 & 0.7254 & 0.4965 & 0.773 & 0.498 & 0.7343 & 0.61285 \\
\hline $\begin{array}{l}\text { BPRS Gunung } \\
\text { Slamet }\end{array}$ & Kab. Cilacap & 2 & 0.6221 & 0.8641 & 0.6521 & 0.9301 & 0.6333 & 0.8248 & 0.656 & 0.8685 & 0.756375 \\
\hline $\begin{array}{l}\text { BPRS } \\
\text { Khasanah } \\
\text { Ummat }\end{array}$ & $\begin{array}{l}\text { Kab. } \\
\text { Banyumas }\end{array}$ & 2 & 0.5618 & 0.7105 & 0.5558 & 0.7655 & 0.5309 & 0.7509 & 0.5337 & 0.6543 & 0.632925 \\
\hline $\begin{array}{l}\text { BPRS Arta } \\
\text { Leksana }\end{array}$ & $\begin{array}{l}\text { Kab. } \\
\text { Banyumas }\end{array}$ & 2 & 0.5373 & 0.7852 & 0.5499 & 0.7657 & 0.5767 & 0.7033 & 0.5686 & 0.6535 & 0.642525 \\
\hline $\begin{array}{l}\text { BPRS Meru } \\
\text { Sankara }\end{array}$ & Kab. Magelang & 2 & 0.4829 & 0.6702 & 0.6291 & 0.859 & 0.4843 & 0.6928 & 0.4827 & 0.6564 & 0.619675 \\
\hline $\begin{array}{l}\text { BPRS Al } \\
\text { Mabrur }\end{array}$ & Kab. Klaten & 2 & 0.9322 & 0.834 & 0.6013 & 0.8321 & 0.5843 & 0.78 & 0.4764 & 0.7435 & 0.722975 \\
\hline $\begin{array}{l}\text { BPRS Artha } \\
\text { Amanah } \\
\text { Ummat }\end{array}$ & $\begin{array}{l}\text { Kab. } \\
\text { Semarang }\end{array}$ & 1 & 0.6428 & 0.8421 & 0.5988 & 0.8609 & 0.614 & 0.8544 & 0.5853 & 0.8287 & 0.728375 \\
\hline $\begin{array}{l}\text { BPRS Dana } \\
\text { Mulia }\end{array}$ & $\begin{array}{l}\text { Kota } \\
\text { Surakarta/Solo }\end{array}$ & 2 & 0.5528 & 0.6844 & 0.584 & 0.7309 & 0.5681 & 0.5311 & 0.4278 & 0.5558 & 0.5793625 \\
\hline $\begin{array}{l}\text { BPRS Madina } \\
\text { Mandiri } \\
\text { Sejahtera }\end{array}$ & Kab. Bantul & 3 & 0.6784 & 0.9214 & 0.6574 & 1 & 0.2998 & 0.5292 & 0.5655 & 0.7256 & 0.6721625 \\
\hline $\begin{array}{l}\text { BPRS Barokah } \\
\text { Dana Sejahtera }\end{array}$ & $\begin{array}{l}\text { Kota } \\
\text { Yogyakarta }\end{array}$ & 2 & 0.4767 & 0.6502 & 0.5467 & 0.6982 & 0.542 & 0.7345 & 0.5476 & 0.7534 & 0.6186625 \\
\hline $\begin{array}{l}\text { BPRS Al } \\
\text { Mabrur } \\
\text { Babadan }\end{array}$ & Kab. Ponorogo & 3 & 0.5388 & 1 & 1 & 1 & 1 & 1 & 0.9706 & 0.9046 & 0.92675 \\
\hline $\begin{array}{l}\text { BPRS Rahma } \\
\text { Syariah }\end{array}$ & Kab. Kediri & 2 & 0.4641 & 0.6434 & 0.4515 & 0.8122 & 0.4565 & 0.6777 & 0.4841 & 0.6567 & 0.580775 \\
\hline $\begin{array}{l}\text { BPRS Bhakti } \\
\text { Haji }\end{array}$ & Kab. Malang & 2 & 0.5532 & 0.8803 & 0.5758 & 0.706 & 0.4639 & 0.7239 & 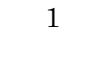 & 0.6727 & 0.696975 \\
\hline $\begin{array}{l}\text { BPRS } \\
\text { Situbondo }\end{array}$ & $\begin{array}{l}\text { Kab. } \\
\text { Situbondo }\end{array}$ & 3 & 0.4981 & 0.7415 & 0.479 & 0.7056 & 0.5088 & 0.6907 & 0.4365 & 0.7192 & 0.597425 \\
\hline $\begin{array}{l}\text { BPRS Jabal } \\
\text { Tsur }\end{array}$ & Kab. Sidoarjo & 2 & 0.5443 & 0.8085 & 0.566 & 0.8056 & 0.5131 & 0.8138 & 0.4752 & 0.7216 & 0.6560125 \\
\hline $\begin{array}{l}\text { BPRS Unawi } \\
\text { Barokah }\end{array}$ & Kab. Sidoarjo & 2 & 0.4413 & 0.6653 & 0.4767 & 0.6154 & 1 & 0.6589 & 0.5115 & 0.7977 & 0.64585 \\
\hline BPRS Amanah & Kab. Gresik & 2 & 0.5895 & 0.7285 & 0.4861 & 0.6167 & 0.4447 & 0.6271 & 0.3258 & 0.5282 & 0.543325 \\
\hline $\begin{array}{l}\text { BPRS Sarana } \\
\text { Prima Mandiri }\end{array}$ & $\begin{array}{l}\text { Kab. } \\
\text { Pamekasan }\end{array}$ & 2 & 0.4548 & 0.6154 & 0.4899 & 0.6516 & 0.515 & 0.8876 & 0.5011 & 0.7002 & 0.60195 \\
\hline $\begin{array}{l}\text { BPRS Al } \\
\text { Attaqwa } \\
\text { Garuda Utama }\end{array}$ & $\begin{array}{l}\text { Kab. } \\
\text { Tangerang }\end{array}$ & 1 & 0.4968 & 0.5765 & 0.5524 & 0.806 & 0.4925 & 0.6325 & 0.4853 & 0.6 & 0.58025 \\
\hline $\begin{array}{l}\text { BPRS } \\
\text { Wakalumi }\end{array}$ & $\begin{array}{l}\text { Kab. } \\
\text { Tangerang }\end{array}$ & 1 & 0.5618 & 0.6932 & 0.5258 & 0.7142 & 0.5872 & 0.7148 & 0.5476 & 0.6669 & 0.6264375 \\
\hline $\begin{array}{l}\text { BPRS Berkah } \\
\text { Ramadhan }\end{array}$ & $\begin{array}{l}\text { Kab. } \\
\text { Tangerang }\end{array}$ & 1 & 0.4347 & 0.6881 & 0.4777 & 0.6808 & 0.4723 & 0.653 & 0.5163 & 0.7591 & 0.58525 \\
\hline
\end{tabular}


Avalaible online at http://journals.ums.ac.id, Permalink/DOI: 10.23917/jep.v20i1.6692

Jurnal Ekonomi Pembangunan: Kajian Masalah Ekonomi dan Pembangunan, 20 (1), 2019, 28-49

\begin{tabular}{|c|c|c|c|c|c|c|c|c|c|c|c|}
\hline Nama BPRS & Kab. Kota & ZONA & 2012.1 & 2012.2 & 2013.1 & 2013.2 & 2014.1 & 2014.2 & 2015.1 & 2015.2 & AVERAGE \\
\hline $\begin{array}{l}\text { BPRS } \\
\text { Muamalah } \\
\text { Cilegon }\end{array}$ & Kab. Serang & 2 & 0.4821 & 0.6336 & 0.4528 & 0.5767 & 0.3999 & 0.5387 & 0.414 & 0.5021 & 0.4999875 \\
\hline $\begin{array}{l}\text { BPRS Harta } \\
\text { Insan Karimah }\end{array}$ & $\begin{array}{l}\text { Kota } \\
\text { Tangerang }\end{array}$ & 1 & 0.9724 & 1 & 1 & 1 & 0.9771 & 0.9776 & 0.8071 & 0.9151 & 0.9561625 \\
\hline $\begin{array}{l}\text { BPRS Mulia } \\
\text { Berkah Abadi }\end{array}$ & $\begin{array}{l}\text { Kota } \\
\text { Tangerang }\end{array}$ & 1 & 0.6075 & 0.7777 & 0.5609 & 0.801 & 0.5006 & 0.578 & 0.6084 & 0.7375 & 0.64645 \\
\hline $\begin{array}{l}\text { BPRS Syariat } \\
\text { Fajar Sejahtera } \\
\text { Bali }\end{array}$ & Kab. Badung & 2 & 0.6853 & 0.8422 & 1 & 1 & 1 & 1 & 0.6783 & 1 & 0.900725 \\
\hline
\end{tabular}

